\title{
A possible association between the -2518 A>G MCP-1 polymorphism and insulin resistance in school children
}

1 Facultad de Ciencias Químico Biológicas, Universidad Autónoma de Guerrero, Chilpancingo, Guerrero, México

${ }^{2}$ Instituto de Investigación en Ciencias Biomédicas, Departamento de Biología Molecular y Genómica, Centro Universitario de Ciencias de la Salud, Universidad de Guadalajara, Jalisco, México ${ }^{3}$ Facultad de Medicina, Universidad Autónoma de Guerrero, Acapulco, Guerrero, México ${ }^{4}$ Cátedra CONACyT, Facultad de Ciencias Químico Biológicas, Universidad Autónoma de Guerrero, Chilpancingo, Guerrero, México

${ }^{5}$ Laboratorio de Investigación en Obesidad y Diabetes, Facultad de Ciencias Químico Biológicas, Universidad Autónoma de Guerrero, Ciudad Universitaria, Guerrero, México

\author{
Correspondence to: \\ Isela Parra-Rojas \\ Laboratorio de Investigación \\ en Obesidad y Diabetes, \\ Facultad de Ciencias \\ Químico Biológicas, \\ Universidad Autónoma de Guerrero, \\ Ciudad Universitaria, \\ Chilpancingo 39090, \\ Guerrero, México \\ iprojas@yahoo.com
}

Received on Feb/6//2017

Accepted on Aug/9/2017

DOI: $10.20945 / 2359-3997000000012$
Inés Matia-García', Lorenzo Salgado-Goytia', Luz Elena Ramos-Arellano', José Francisco Muñoz-Valle², Adakatia Armenta-Solís ${ }^{3}$, Olga Lilia Garibay-Cerdenares ${ }^{4}$, Mónica Ramírez ${ }^{4}$, Isela Parra-Rojas ${ }^{5}$

\begin{abstract}
Objective: Monocyte chemoattractant protein 1 (MCP-1) has been suggested to be involved in the pathophysiology of insulin resistance (IR); therefore, variants in the MCP-1 gene may contribute to the development of this disease. The aim of this study was to analyze the relationship of the -2518 A>G MCP-1 (rs1024611) gene polymorphism with insulin resistance in Mexican children. Subjects and methods: A cross-sectional study was performed in 174 children, including 117 children without insulin resistance and 57 children with IR, with an age range of 6-11 years. Levels for serum insulin and high-sensitivity $\mathrm{C}$-reactive protein were determined. The $-2518 \mathrm{~A}>\mathrm{G} M C P-1$ polymorphism was identified by the polymerase chain reaction-restriction fragment length polymorphism method. Insulin resistance was defined as a HOMA-IR in the upper $75^{\text {th }}$ percentile, which was $\geq 2.4$ for all children. Results: Genotype frequencies of the rs 1024611 polymorphism for the insulin-sensitive group were $17 \% \mathrm{AA}, 48 \% \mathrm{AG}$ and $35 \% \mathrm{GG}$, and the frequency of $\mathrm{G}$ allele was $59 \%$, whereas frequencies for the insulin-resistant group were $12 \% \mathrm{AA}, 37 \% \mathrm{AG}$ and $51 \% \mathrm{GG}$, and the frequency of $\mathrm{G}$ allele was $69 \%$. The genotype and allele frequencies between groups did not show significant differences. However, the GG genotype was the most frequent in children with IR. The GG genotype was associated with insulin resistance $(\mathrm{OR}=2.2, P=0.03$ ) in a genetic model. Conclusion: The $-2518 \mathrm{~A}>\mathrm{G} M C P-1$ gene polymorphism may be related to the development of insulin resistance in Mexican children. Arch Endocrinol Metab. 2018;62(1):72-9
\end{abstract}

\section{Keywords}

Insulin resistance; MCP-1; polymorphism; obesity; children

\section{INTRODUCTION}

$\mathrm{T}$ he marked increase in pediatric obesity in the past decade has resulted in unprecedented increases in the incidence of type 2 diabetes mellitus among children and adolescents $(1,2)$. There is substantial evidence that obesity is the main determinant of insulin resistance in children and that it increases the risk not only for the metabolic syndrome in adulthood but also for cardiovascular disease and type 2 diabetes later in life $(3,4)$.

Obesity is associated with a chronic low-grade inflammatory state, characterized by enhanced production of multiple cytokines and chemokines. Monocyte chemoattractant protein-1 (MCP-1) is a chemokine produced by adipose tissue and other tissues. The production of MCP-1 in obesity is triggered when adipocytes are exposed to inflammatory cytokines and fatty acids. Other cells that produce MCP-1 in obesity include hepatocytes, skeletal muscle cells, monocytes, vascular smooth muscle and endothelial cells. MCP-1 production results in initiation and propagation of the inflammatory response in obesity $(5,6)$. Some studies have found that plasma levels of MCP-1 are increased in obese adults (7) and in obese children (8) compared to lean controls. Furthermore, MCP-1 signaling has a direct role in the development of obesity. Younce and cols. reported that MCP-1-induced adipogenesis in 3T3-Ll cells is independent of PPAR gamma activation (9). 
Mice with CCR2 deficiency had attenuated deposition of visceral fat and insulin resistance when challenged with a high fat diet (10). Moreover, $M C P-1$ had an angiogenic effect on endothelial cells (11); therefore, it can contribute to the expansion and remodeling of adipose tissue (12).

In diabetic subjects, the high glucose-induced inflammatory process is characterized by the cooperation of a complex network of inflammatory molecules, such as cytokines, adhesion molecules, growth factors, and chemokines. The high glucose concentration induces an increase in the synthesis and release of MCP-1 by endothelial cells (EC) and smooth muscle cells (SMC) (13). MCP-1 is a potent chemotactic factor that regulates monocyte and macrophage migration and infiltration at sites of inflammation (14). The interaction of MCP-1 with its receptor CCR2 is considered pivotal in obesity-induced insulin resistance. Several groups have reported that mice with targeted deletions in the genes for MCP-1/CCL2 and its receptor CCR2 have reduced adipose tissue macrophage (ATM) content, decreased inflammation in fat and protection from high-fat (HF) diet-induced insulin resistance (15). Conversely, mice overexpressing MCP-1 in adipose tissue have an increased number of ATMs along with insulin resistance (16). Therefore, the MCP-1-CCR2 axis is of central importance for promoting ATM recruitment and insulin resistance in mice. Zineh and cols. reported that serum levels of MCP-1 increased in children with type 1 diabetes compared with the control group (17). In another study in adult subjects, serum concentrations of MCP-1 were higher in patients with type 2 diabetes than in normal subjects (18). The glucose and insulin appear to exert effects on MCP-1 secretion, and this interaction might be important for the development of insulin resistance in children (19).

A single nucleotide polymorphism characterized by a chance of $\mathrm{A}>\mathrm{G}$ at position -2518 in the MCP-1 distal promoter regulatory region affects MCP-l's transcription activity in response to IL-1 $\beta$ (20). This polymorphism has been associated with the development of chronic diseases such as obesity, hypertension, atherosclerosis, type 2 diabetes and insulin resistance (21-23). Briefly, in a German population, the MCP-I $-2518 \mathrm{G}$ allele was associated with decreased prevalence of insulin resistance and type 2 diabetes (24). Another study carried out in a Japanese population found that in obese diabetics, -2518AA carriers had increased insulin resistance compared to -2518GG carriers (23).
Alternatively, in an adult population of western Mexico, it was found that subjects without insulin resistance presented the $-2518 \mathrm{~A}$ allele more frequently than their counterparts with IR (25). In light of these contradictory results, it is important to perform replication studies in different populations to determine the association of this polymorphism with insulin resistance. In the Mexican population, the distributions of genotypic frequencies of this polymorphism in adults and its relations with bladder cancer and tuberculosis have been reported $(26,27)$. Genotypic frequencies and their possible relationship to insulin resistance have not been identified in children. The aim of this study was to investigate whether the $-2518 \mathrm{~A}>\mathrm{G} M C P-1$ polymorphism is associated with insulin resistance in Mexican children.

\section{SUBJECTS AND METHODS}

\section{Subjects}

We analyzed a total of 174 unrelated children (86 girls and 88 boys), with an age range of 6-11 years, who were divided into two groups: 117 children without IR and 57 children with IR. The participants were all born in the State of Guerrero, Mexico, with a family history of ancestors, at least back to the third generation, born in this state. All children with evidence of infectious disease or with any treatment that could influence biochemical or hematological parameters were excluded from the study. Informed written consent was obtained from all parents or guardians before enrollment of children in the study according to the ethical guidelines of the 2008 Declaration of Helsinki. Approval for the study was obtained from the Research Ethics Committee of the University of Guerrero.

\section{Clinical and anthropometric measurements}

Body weight was determined in light clothes and without shoes using a body composition monitor (Tanita BC-553, Arlington, USA). Height and body circumferences were measured with a stadiometer and anthropometric tape (Seca, Hamburg, Germany), respectively. The classification of obesity was made using the 2000 Centers for Disease Control and Prevention growth charts, with normal weight defined as the $5^{\text {th }}$ $85^{\text {th }}$ percentiles and obesity as $\geq 95^{\text {th }}$ percentile (28). The four skinfold thicknesses (triceps, biceps, subscapular and suprailiac) were measured with a plicometer 
(Dynatronics Co, Salt Lake City, USA) and blood pressure (BP) with an aneroid sphygmomanometer (Riester CE 0124, Jungingen, Germany). Hypertension was defined as systolic or diastolic blood pressure in the $95^{\text {th }}$ percentile or higher for age and sex, using an average of 2 measurements (29).

\section{Laboratory assessment}

A fasting blood sample was obtained from each child by antecubital venipuncture. Serum glucose levels were analyzed with semi-automated equipment (COBAS MIRA), and insulin levels were measured using an enzyme-linked immunosorbent assay (GenWay INS-EASIA kit). Intra-assay and inter-assay variation coefficients were $4.8 \%$ and $8.1 \%$, respectively, and the detection limit was $0.17 \mu \mathrm{U} / \mathrm{mL}$. The homeostasis model assessment of insulin resistance was used to determine insulin resistance in children. This score was calculated with the following formula: fasting serum insulin $(\mu \mathrm{U} / \mathrm{mL}) \mathrm{x}$ fasting plasma glucose $(\mathrm{mmol} / \mathrm{L}) / 22.5(30)$. Insulin resistance was defined as a HOMA-IR at or above the $75^{\text {th }}$ percentile, which was $\geq 2.4$ for all children. Leukocyte and platelet counts were determined using an ADVIA-60 (Bayer Diagnostics). High-sensitivity C-reactive protein (hsCRP) levels were measured by a turbidimetry assay (BioSystems SA) with a sensitivity of $0.06 \mathrm{mg} / \mathrm{L}$ and intra-assay and inter-assay variation coefficients of $1.8 \%$ and $3.6 \%$, respectively.

\section{Genotyping analysis}

Genomic DNA (gDNA) was extracted from peripheral leukocytes obtained from whole blood samples, according to the Miller method. The analysis of the -2518 A>G MCP-1 (rs1024611) polymorphism was performed by the polymerase chain reactionrestriction fragment length polymorphism (PCRRFLP) method, using the following primers: 5'CACAGAGAGAGTCTGGCCACGT3' (forward) and 5'CCAACAGAGGACTCTTGGTCT3' (reverse). The reaction was carried out in a final volume of $20 \mu \mathrm{l}$, adding buffer $1 \mathrm{X}$ to $2.5 \mathrm{mM} \mathrm{MgCl}, 0.2 \mathrm{mM}$ dNTPs, $0.2 \mathrm{mM}$ of each primer, $2.0 \mathrm{U} / \mu \mathrm{l} \mathrm{Taq}$ polymerase (Invitrogen Life Technologies) and $0.1 \mu \mathrm{g} / \mathrm{mL}$ of gDNA. PCR was performed with an initial denaturation at $94^{\circ} \mathrm{C}$ for $5 \mathrm{~min}$, followed by 25 cycles of amplification consisting of $94{ }^{\circ} \mathrm{C}$ for $30 \mathrm{~s}$ of denaturation, $63{ }^{\circ} \mathrm{C}$ for $30 \mathrm{~s}$ of annealing and $72{ }^{\circ} \mathrm{C}$ for $30 \mathrm{~s}$ of extension, and a final extension step at $72{ }^{\circ} \mathrm{C}$ for $5 \mathrm{~min}$. The amplified product of $234 \mathrm{bp}$ was digested with PvuII restriction enzyme (New England Biolabs) for 2 hours at $37{ }^{\circ} \mathrm{C}$ and analyzed by electrophoresis in 6\% polyacrylamide gel (Invitrogen ${ }^{\mathrm{TM}}$ life technologies) stained with silver nitrate. The AA genotype lacking the PvII site migrated as a 234 bp fragment, whereas the GG genotype was cleaved and appeared as 159 bp and 75 bp fragments.

\section{Statistical analysis}

The analysis was performed with STATA software (V.9.2). Differences in variables between groups were evaluated using a chi-square test for categorical variables, Student's $t$ test for continuous variables with symmetrical distributions (data are presented as the mean and standard deviation), and a Mann-Whitney $\mathrm{U}$ test for variables without symmetrical distributions (data are presented as median and $5^{\text {th }}$ to $95^{\text {th }}$ percentiles). The genotype and allele frequencies were determined by direct counting, and a chi-square test was used to calculate the Hardy-Weinberg Equilibrium in case and control groups. To evaluate the association between insulin resistance and the polymorphism under investigation, we used a logistic regression model that was adjusted by age, gender, obesity and hypertension. $P$ values $<0.05$ were considered significant.

\section{RESULTS}

The study was conducted in a total of 174 children, divided into two groups: 117 children without IR were recruited as a control group, and 57 children with IR were the case group. The descriptive characteristics of the participants are summarized in Table 1 . The median age of the children was 9 years, without differences between groups in age or gender. The insulin-resistant children had increases in all measures of central and peripheral adiposity and in both systolic and diastolic blood pressure compared to the group with insulin sensitivity. We found a high prevalence of obesity $(73.7 \%)$ in the insulin-resistant group compared with the insulin-sensitive group (36.8\%). The group with IR also showed an increase in serum hsCRP levels but not in leukocyte or platelet counts.

Demographic, clinical and metabolic variables were compared between children grouped according to their genotypes of the $-2518 \mathrm{~A}>\mathrm{G}$ MCP-1 polymorphism. Although three genetic models were performed, 
Table 1. Clinical and laboratory variables of the studied groups

\begin{tabular}{|c|c|c|c|c|}
\hline Variables & $\begin{array}{l}\text { All children } \\
(\mathrm{n}=174)\end{array}$ & $\begin{array}{l}\text { Group without IR } \\
\qquad(\mathrm{n}=117)\end{array}$ & $\begin{array}{l}\text { Group with IR } \\
\quad(\mathrm{n}=57)\end{array}$ & $P$ value \\
\hline Age (years) $)^{\ddagger}$ & $9(6-11)$ & $9(6-11)$ & $9(6-11)$ & 0.08 \\
\hline Gender $\%(n)^{*}$ & & & & 0.36 \\
\hline Male & $50.6(88)$ & $53(62)$ & $45.6(26)$ & \\
\hline Female & $49.4(86)$ & $47(55)$ & $54.4(31)$ & \\
\hline Weight $(\mathrm{kg})^{\ddagger}$ & $33.2(20.1-59.1)$ & $30.7(19.7-48.8)$ & 44.4 (23-68.2) & $<0.001$ \\
\hline Height $(\mathrm{cm})^{\dagger}$ & $132.6 \pm 11.3$ & $131.1 \pm 10.6$ & $137.2 \pm 12.1$ & 0.001 \\
\hline BMI $\left(\mathrm{kg} / \mathrm{m}^{2}\right)^{\ddagger}$ & $18.4(14.3-27)$ & $17.3(14.1-24.9)$ & $23.5(14.9-29.9)$ & $<0.001$ \\
\hline Obesity \% $(n)^{*}$ & & & & $<0.001$ \\
\hline No & $51.1(89)$ & $63.2(74)$ & $26.3(15)$ & \\
\hline Yes & $48.9(85)$ & $36.8(43)$ & $73.7(42)$ & \\
\hline Waist circumference $(\mathrm{cm})^{\ddagger}$ & $67(54-88)$ & $66(53-84)$ & $80.3(58-96)$ & $<0.001$ \\
\hline Hip circumference $(\mathrm{cm})^{\ddagger}$ & $75(62-96)$ & $73(62-89)$ & $85(66-104)$ & $<0.001$ \\
\hline Waist-to-hip ratio ${ }^{\ddagger}$ & $0.9(0.8-0.97)$ & $0.9(0.8-0.97)$ & $0.9(0.8-1.0)$ & 0.001 \\
\hline Arm circumference $(\mathrm{cm})^{\ddagger}$ & $21(16-28)$ & $20(16-26)$ & $24.5(17-33)$ & $<0.001$ \\
\hline Biceps skinfold $(\mathrm{mm})^{\dagger}$ & $15.5 \pm 4.8$ & $14.8 \pm 4.8$ & $17.6 \pm 4.3$ & $<0.001$ \\
\hline Triceps skinfold $(\mathrm{mm})^{\ddagger}$ & $15(8.5-21.5)$ & $13.5(8-21.5)$ & $18(10-22)$ & $<0.001$ \\
\hline Subscapular skinfold $(\mathrm{mm})^{\ddagger}$ & $13(6-22)$ & $12(5.5-21)$ & $18.5(8-25)$ & $<0.001$ \\
\hline Suprailiac skinfold $(\mathrm{mm})^{\dagger}$ & $17.9 \pm 5.5$ & $17.0 \pm 5.5$ & $20.7 \pm 4.7$ & $<0.001$ \\
\hline $\mathrm{SBP}(\mathrm{mmHg})^{\ddagger}$ & $98(81-115)$ & $96(81-110)$ & $101(80-124)$ & $<0.001$ \\
\hline $\mathrm{DBP}(\mathrm{mmHg})^{\ddagger}$ & $58(48-71)$ & $57(48-68)$ & $60(44.5-78)$ & $<0.001$ \\
\hline Glucose $(\mathrm{mg} / \mathrm{dL})^{\ddagger}$ & $96(74-112)$ & $95(72-112)$ & $98(78-114)$ & 0.06 \\
\hline Insulin $(\mu \mathrm{U} / \mathrm{mL})^{\ddagger}$ & $6.9(0.8-22.4)$ & $4.7(0.6-9.2)$ & $13.7(9.9-31.9)$ & $<0.001$ \\
\hline HOMA-IR $\mathbb{R}^{\ddagger}$ & $1.2(0 .-4.9)$ & $0.6(0-2.1)$ & $3.1(2.5-7.3)$ & $<0.001$ \\
\hline $\operatorname{hsCRP}(\mathrm{mg} / \mathrm{L})^{\ddagger}$ & $0.8(0.1-6.5)$ & $0.6(0.1-6.0)$ & $1.6(0.1-8.3)$ & 0.004 \\
\hline Leukocytes $\left(10^{3} / \mathrm{mm}^{3}\right)^{\ddagger}$ & $7.7(5.0-12.3)$ & $7.6(5.0-12.5)$ & $7.9(5-11.5)$ & 0.08 \\
\hline Platelets $\left(10^{3} / \mathrm{mm}^{3}\right)^{\ddagger}$ & $308(219-413)$ & $306(219-440)$ & $316(218-410)$ & 0.22 \\
\hline
\end{tabular}

* Values are expressed as percentages and $n$. Chi-square test. ${ }^{\dagger}$ Values are expressed as the means \pm SD. Student's $t$ test. ${ }^{\ddagger}$ Values are expressed as median (p5-p95). Mann-Whitney test. IR: insulin resistance; BMI: body mass index; SBP: systolic blood pressure; DBP: diastolic blood pressure; HOMA-IR: homeostasis model of assessment-insulin resistance; hsCRP: high sensitivity C-reactive protein.

the table only includes the comparison that shows significant differences. All children were divided into two groups, carriers and non-carriers of the A allele (AA+AG vs. $G G)$. Interestingly, the $G$ allele was the most frequent in children with insulin resistance (69\%). However, we found that some A allele carriers also had insulin resistance $(31 \%)$ (Table 2$)$.

The $-2518 \mathrm{~A}>\mathrm{G}$ MCP-1 polymorphism was found in Hardy Weinberg Equilibrium in the total population $\left(\mathrm{X}^{2}\right.$ $=0.57, \mathrm{P}=0.45)$, in cases $\left(\mathrm{X}^{2}=1.03, \mathrm{P}=0.31\right)$ and in controls $\left(\mathrm{X}^{2}=0.014, P=0.91\right)$. The comparative analysis of genotype and allele frequencies between groups did not show significant differences; however, we found an association of the GG genotype with insulin resistance $(\mathrm{OR}=2.2,95 \% \mathrm{CI}, 1.1-4.5 ; \mathrm{P}=0.03)$, determined by an adjusted genetic model (Table 3 ).

\section{DISCUSSION}

In this study, an association between the $-2518 \mathrm{~A}>\mathrm{G}$ MCP-1 polymorphism and insulin resistance is shown in a sample of Mexican children. Our results indicate that children with the GG genotype have a 2.2-fold higher risk of developing IR in comparison to those with the AA or AG genotype.

In contrast, a study in a German population found a low prevalence of insulin resistance and type 2 diabetes in carriers of the $G$ allele compared with subjects homozygous for the A allele (24). In another study in a Chinese population, the $\mathrm{G}$ allele proved to be protective (adjusted OR $=0.49,95 \%$ CI, 0.32-0.77; $\mathrm{P}<0.0001$ ) against type 2 diabetes compared with subjects homozygous for allele A (31). These results 
Table 2. Clinical and laboratory variables according to MCP-1 genotypes

\begin{tabular}{|c|c|c|c|c|}
\hline Variables & $\begin{array}{c}\text { All children } \\
(n=174)\end{array}$ & $\begin{array}{c}A A+A G \\
(n=104)\end{array}$ & $\begin{array}{c}G G \\
(n=70)\end{array}$ & $P$ value \\
\hline Age $(\text { years) })^{\ddagger}$ & $9(6-11)$ & $9(6-11)$ & $9(6-11)$ & 0.39 \\
\hline Gender \% $(n)^{*}$ & & & & 0.42 \\
\hline Male & $50.6(88)$ & $48.1(50)$ & $54.3(38)$ & \\
\hline Female & $49.4(86)$ & $51.9(54)$ & 45.7 (32) & \\
\hline Weight $(\mathrm{kg})^{\ddagger}$ & 34.1 (20.1-59.2) & $32.1(20.3-59.1)$ & $36.2(20.1-64.9)$ & 0.13 \\
\hline Height $(\mathrm{cm})^{\dagger}$ & $133.4 \pm 11.5$ & $132.6 \pm 11.1$ & $134.6 \pm 12.2$ & 0.26 \\
\hline $\mathrm{BMI}\left(\mathrm{kg} / \mathrm{m}^{2}\right)^{\ddagger}$ & $18.9(14.3-28.2)$ & $18.4(14.3-25.9)$ & $19.7(14.5-29.1)$ & 0.08 \\
\hline Obesity \% (n) ${ }^{*}$ & & & & 0.57 \\
\hline No & $51.1(89)$ & $53(55)$ & $49(34)$ & \\
\hline Yes & $48.9(85)$ & $47(49)$ & $51(36)$ & \\
\hline Waist circumference $(\mathrm{cm})^{\ddagger}$ & $67.5(54-90)$ & $67(54-89)$ & $70(56-94)$ & 0.10 \\
\hline Hip circumference $(\mathrm{cm})^{\ddagger}$ & $76(62-96.5)$ & $74(62-96)$ & $79(62-96.5)$ & 0.15 \\
\hline Waist-to-hip ratio & $0.9(0.8-0.97)$ & $0.9(0.8-0.97)$ & $0.9(0.8-0.97)$ & 0.24 \\
\hline Arm circumference $(\mathrm{cm})^{\ddagger}$ & $21(16-29)$ & $21(16.5-28)$ & $22(16-30)$ & 0.20 \\
\hline Biceps skinfold $(\mathrm{mm})^{\dagger}$ & $15.6 \pm 4.6$ & $15.7 \pm 4.9$ & $15.5 \pm 4.1$ & 0.76 \\
\hline Triceps skinfold $(\mathrm{mm})^{\ddagger}$ & $15(8.5-21.5)$ & $15(8.5-21)$ & $15(7.5-22)$ & 0.97 \\
\hline Subscapular skinfold $(\mathrm{mm})^{\ddagger}$ & $13(6-22.5)$ & $12.8(5.5-21.5)$ & $13.5(6-23)$ & 0.65 \\
\hline Suprailiac skinfold $(\mathrm{mm})^{\dagger}$ & $18.2 \pm 5.6$ & $18.1 \pm 5.5$ & $18.2 \pm 5.9$ & 0.95 \\
\hline $\mathrm{SBP}(\mathrm{mmHg})^{\ddagger}$ & $98(80-115)$ & $98(80-117)$ & $98(81-110)$ & 0.82 \\
\hline $\mathrm{DBP}(\mathrm{mmHg})^{\ddagger}$ & $58(49-71)$ & $58(49-72)$ & $58.5(50-70)$ & 0.83 \\
\hline Hypertension \% (n) ${ }^{\star}$ & & & & 0.47 \\
\hline No & $92.5(161)$ & $91.3(95)$ & $94.3(66)$ & \\
\hline Yes & $7.5(13)$ & $8.7(9)$ & $5.7(4)$ & \\
\hline Glucose $(\mathrm{mg} / \mathrm{dL})^{\ddagger}$ & $96(73-109)$ & $96.5(72-109)$ & $95.5(78-112)$ & 0.71 \\
\hline Insulin $(\mu \mathrm{U} / \mathrm{mL})^{\ddagger}$ & $6.9(0.8-22.4)$ & $6.6(1.0-21.5)$ & $8.2(0.8-22.4)$ & 0.17 \\
\hline HOMA-IR ${ }^{\ddagger}$ & $1.7(0.2-5.5)$ & $1.5(0.2-4.8)$ & $1.9(0.2-5.8)$ & 0.15 \\
\hline Insulin resistance $\%(n)^{*}$ & & & & 0.04 \\
\hline No & $67.2(117)$ & $73.1(76)$ & $58.6(41)$ & \\
\hline Yes & $32.8(57)$ & $26.9(28)$ & $41.4(29)$ & \\
\hline $\mathrm{hsCRP}(\mathrm{mg} / \mathrm{L})^{\ddagger}$ & $0.8(0.1-6.5)$ & $0.8(0.1-8.0)$ & $0.9(0.1-6.3)$ & 0.99 \\
\hline Leukocytes $\left(10^{3} / \mathrm{mm}^{3}\right)^{\ddagger}$ & $7.6(4.8-11.5)$ & $7.7(4.8-12.3)$ & $7.6(5.1-11.2)$ & 0.64 \\
\hline Platelets $\left(10^{3} / \mathrm{mm}^{3}\right)^{\ddagger}$ & 308 (219-412) & $310.5(224-413)$ & $306(205-410)$ & 0.66 \\
\hline
\end{tabular}

${ }^{*}$ Values are expressed as percentages and $n$. Chi-square test. ${ }^{\dagger}$ Values are expressed as the means $\pm \mathrm{SD}$. Student's $t$ test. ${ }^{\ddagger}$ Values are expressed as median (p5-p95). Mann-Whitney test. IR: insulin resistance; BMI: body mass index; SBP: systolic blood pressure; DBP: diastolic blood pressure; HOMA-IR: homeostasis model of assessment-insulin resistance; hsCRP: high sensitivity C-reactive protein.

suggest a protective role of the $G$ allele for the development of insulin resistance and type 2 diabetes in the Chinese population. These differences may be attributed to the ancestry of the population; it is known that the Mexican population originated from mixed racial ancestry consisting of individuals from Europe (mainly Spain) or Africa who migrated to America where Native Americans of this region were living, giving origin to the Mexican mestizo population, who present a greater genetic diversity. This diversity can cause marked differences in allelic frequencies and patterns of linkage disequilibrium across their genome (32).

There are few studies reporting an association of $-2518 \mathrm{~A}>\mathrm{G}$ polymorphism with insulin resistance and type 2 diabetes, but other investigators have found associations of the GG genotype with high serum MCP-1 levels, hypertension, lupus nephritis and tuberculosis $(27,33,34)$. 
Table 3. Association of insulin resistance with genotype and allele frequencies of $M C P$-1 polymorphism

\begin{tabular}{|c|c|c|c|c|c|}
\hline Genotype/allele & $\begin{array}{c}\text { Group without IR } \\
(\mathrm{n}=117) \\
\%(\mathrm{n})\end{array}$ & $\begin{array}{l}\text { Group with IR } \\
\text { (n=57) } \\
\%(n)\end{array}$ & $P^{\dagger}$ & $\begin{array}{l}\text { OR crude } \\
(95 \% \text { CI); } P\end{array}$ & $\begin{array}{l}\text { OR adjusted } \\
(95 \% \mathrm{Cl}) ; P^{\ddagger}\end{array}$ \\
\hline Frequencies & & & 0.13 & & \\
\hline$A A^{*}$ & $17(20)$ & $12(7)$ & & 1 & \\
\hline$A G$ & $48(56)$ & $37(21)$ & & $1.1(0.4-2.9) ; 0.89$ & \\
\hline GG & $35(41)$ & $51(29)$ & & $2.0(0.8-5.4) ; 0.16$ & \\
\hline Frequencies & & & 0.08 & & \\
\hline$A^{*}$ & $41(96)$ & $31(35)$ & & 1 & \\
\hline$G$ & $59(138)$ & $69(79)$ & & $1.6(1.0-2.6) ; 0.06$ & \\
\hline Dominant model & & & 0.41 & & \\
\hline$A A^{*}$ & $17(20)$ & $12(7)$ & & 1 & 1 \\
\hline$A G+G G$ & $83(97)$ & $88(50)$ & & $1.5(0.6-3.7) ; 0.41$ & $1.6(0.6-4.3) ; 0.37$ \\
\hline Recessive model & & & 0.04 & & \\
\hline $\mathrm{AA}+\mathrm{AG}^{*}$ & $65(76)$ & $49(28)$ & & 1 & \\
\hline GG & $35(41)$ & $51(29)$ & & $1.9(1.0-3.6) ; 0.04$ & $2.2(1.1-4.5) ; 0.03$ \\
\hline Additive model & - & - & - & $1.5(0.96-2.5) ; 0.07$ & 1.7 (0.98-2.7); 0.05 \\
\hline
\end{tabular}

* Reference category; ${ }^{\dagger}$ Chi square test. ${ }^{\ddagger}$ Genetic model adjusted by age, gender, obesity and hypertension.

IR: insulin resistance; OR: odds ratio.

We found that the GG genotype was associated with an increased risk for developing IR when compared with children carrying other genotypes, which suggest that IR may also be related to increased serum MCP-I levels. In other studies, it was observed that insulin induces substantial expression and secretion of MCP-1, both in vitro in insulin-resistant 3T3-Ll adipocytes and in vivo in insulin-resistant obese mice; thus, MCP-1 was identified as an insulin-response gene (6). This result should be considered with caution, as it is necessary to perform a replication study in a larger sample to confirm these results.

Obesity and IR are characterized by chronic systemic low-grade inflammation. Markers of inflammation, such as tumor necrosis factor alpha (TNF- $\alpha$ ), interleukin-6 (IL-6), CRP and MCP-1, are increased in peripheral blood levels in obesity and are associated with IR and may predict the development of type 2 diabetes (35). In this study, the children with IR showed increased hsCRP levels but not leukocyte or platelet counts. The GG genotype carriers did not present an increase in these markers, which could be an indicator of systemic inflammation not related to the development of insulin resistance in the studied children.

We observed that children with IR showed increases in all measures of central and peripheral adiposity compared to children without IR. Insulin resistance is a hallmark of obesity, emerging early in the metabolic syndrome, and is highly associated with increased visceral adipose tissue mass (36). Adipose tissue in obese subjects is characterized by macrophage infiltration, which is an early event contributing to the development of systemic insulin resistance. Indeed, transgenic mice that overexpress MCP-1 specifically in adipocytes develop adipose tissue inflammation and insulin resistance without obesity (37). This finding indicates that the subcutaneous adiposity may be an important predictor of IR in children.

Two main limitations should be considered in our investigation. First, the small sample size limited the statistical power. Second, MCP-1 levels were not measured, therefore the association of -2518 A $>\mathrm{G}$ polymorphism with MCP-1 levels remains uncertain in our population. Thus, future studies in Mexican children are necessary to determine MCP-1 levels.

In conclusion, the $-2518 \mathrm{~A}>\mathrm{G}$ MCP-1 gene polymorphism may be related to the development of insulin resistance in Mexican children.

Disclosure: no potential conflict of interest relevant to this article was reported.

\section{REFERENCES}

1. Silink M. Childhood diabetes: a global perspective. Horm Res. 2002;57(Suppl. 1):1-5. 
2. Invitti C, Guzzaloni G, Gilardini L, Morabito F, Viberti G. Prevalence and concomitants of glucose intolerance in European obese children and adolescents. Diabetes Care. 2003;26(1):118-24.

3. Caprio S. Insulin resistance in childhood obesity. J Pediatr Endocrinol Metab. 2002;15(Suppl. 1):487-92.

4. Sun SS, Liang R, Huang TT, Daniels SR, Arslanian S, Liu K, et al. Childhood obesity predicts adult metabolic syndrome: the Fels Longitudinal Study. J Pediatr. 2008;152(2):191-200.

5. Samaan MC, Obeid J, Nguyen T, Thabane L, Timmons BW. Chemokine ( $\mathrm{C}-\mathrm{C}$ motif) Ligand 2 is a potential biomarker of inflammation \& physical fitness in obese children: a crosssectional study. BMC Pediatr. 2013;13:47.

6. Sartipy P, Loskutoff DJ. Monocyte chemoattractant protein 1 in obesity and insulin resistance. Proc Natl Acad Sci USA. 2003;100(12):7265-70.

7. Kim CS, Park HS, Kawada T, Kim JH, Lim D, Hubbard NE, et al. Circulating levels of MCP- 1 and IL- 8 are elevated in human obese subjects and associated with obesity-related parameters. Int $\mathrm{J}$ Obes. 2006;30(9):1347-55.

8. Breslin WL, Johnston CA, Strohacker K, Carpenter KC, Davidson TR, Moreno JP, et al. Obese Mexican American children have elevated MCP-1, TNF- $\alpha$, monocyte concentration, and dyslipidemia. Pediatrics. 2012;129(5):e1180-6.

9. Younce CW, Azfer A, Kolattukudy PE. MCP-1 (monocyte chemotactic protein-1) induced protein, a recently identified zinc finger protein, induces adipogenesis in 3T3-L1 pre-adipocytes without peroxisome proliferator activated receptor gamma. J Biol Chem. 2009;284(40):27620-8.

10. Weisberg SP, Hunter D, Huber R, Lemieux J, Slaymaker S, Vaddi $\mathrm{K}$, et al. CCR2 modulates inflammatory and metabolic effects of high-fat feeding. J Clin Invest. 2006;116(1):115-24.

11. Salcedo R, Ponce ML, Young HA, Wasserman K, Ward JM, Kleinman HK, et al. Human endothelial cells express CCR2 and respond to MCP-1: direct role of MCP-1 in angiogenesis and tumor progression. Blood. 2000;96(1):34-40.

12. Panee J. Monocyte Chemoattractant Protein 1 (MCP-1) in obesity and diabetes. Cytokine. 2012;60(1):1-12.

13. Dragomir E, Simionescu M. Monocyte chemoattractant protein-1 a major contributor to the inflammatory process associated with diabetes. Arch Physiol Biochem. 2006;112(4-5):239-44.

14. Deshmane SL, Kremlev S, Amini S, Sawaya BE. Monocyte chemoattractant protein-1 (MCP-1): an overview. J Interferon Cytokine Res. 2009;29(6):313-26.

15. Kanda H, Tateya S, Tamori Y, Kotani K, Hiasa K, Kitazawa R, et al. MCP-1 contributes to macrophage infiltration into adipose tissue, insulin resistance, and hepatic steatosis in obesity. J Clin Invest. 2006;116(6):1494-505.

16. Kamei N, Tobe K, Suzuki R, Ohsugi M, Watanabe T, Kubota N, et al. Overexpression of monocyte chemoattractant protein-1 in adipose tissues causes macrophage recruitment and insulin resistance. J Biol Chem. 2006;281(36):26602-14.

17. Zineh I, Beitelshees AL, Silverstein JH, Haller MJ. Serum monocyte chemoattractant protein-1 concentrations associate with diabetes status but not arterial stiffness in children with type 1 diabetes. Diabetes Care. 2009;32(3):465-7.

18. Mine S, Okada Y, Tanikawa T, Kawahara C, Tabata T, Tanaka Y. Increased expression levels of monocyte CCR2 and monocyte chemoattractant protein-1 in patients with diabetes mellitus. Biochem Biophys Res Commun. 2006;344(3):780-5.

19. Zietz B, Büchler C, Herfarth $H$, Müller-Ladner $U$, Spiegel $D$, Schölmerich J, et al. Caucasian patients with type 2 diabetes mellitus have elevated levels of monocyte chemoattractant protein- 1 that are not influenced by the $-2518 \mathrm{~A} / \mathrm{G}$ promoter polymorphism. Diabetes Obes Metab. 2005;7(5):570-8.
20. Rovin BH, Lu L, Saxena R. A novel polymorphism in the MCP1 gene regulatory region that influences MCP-1 expression. Biochem Biophys Res Commun. 1999;259(2):344-8.

21. Yuasa $S$, Maruyama T,Yamamoto $Y$, Hirose $H$, KawaiT, MatsunagaIrie S, et al. MCP-1 gene A-2518G polymorphism and carotid artery atherosclerosis in patients with type 2 diabetes. Diabetes Res Clin Pract. 2009;86(3):193-8.

22. Gustafson B, Hammarstedt A, Andersson CX, Smith U. Inflamed adipose tissue: a culprit underlying the metabolic syndrome and atherosclerosis. ArteriosclerThromb Vasc Biol. 2007;27(11):2276-83.

23. Kouyama K, Miyake K, Zenibayashi M, HirotaY,TeranishiT, Tamori $Y$, et al. Association of serum MCP-1 concentration and MCP-1 polymorphism with insulin resistance in Japanese individuals with obese type 2 diabetes. Kobe J Med Sci. 2008;53(6):345-54.

24. Simeoni E, Hoffmann MM, Winkelmann BR, Ruiz J, Fleury $\mathrm{S}$, Boehm BO, et al. Association between the A-2518G polymorphism in the monocyte chemoattractant protein-1 gene and insulin resistance and type 2 diabetes mellitus. Diabetologia. 2004;47(9):1574-80

25. Guzmán-Ornelas MO, Petri $M H$, Vázquez-Del Mercado $M$, Chavarría-Ávila E, Corona-Meraz Fl, Ruíz-Quezada SL, et al. CCL2 Serum Levels and Adiposity Are Associated with the Polymorphic Phenotypes -2518A on CCL2 and 64ILE on CCR2 in a Mexican Population with Insulin Resistance. J Diabetes Res. 2016;2016:5675739.

26. Vázquez-Lavista LG, Lima G, Gabilondo F, Llorente L. Genetic association of monocyte chemoattractant protein 1 (MCP-1) -2518 polymorphism in Mexican patients with transitional cell carcinoma of the bladder. Urology. 2009;74(2):414-8.

27. Flores-Villanueva PO, Ruiz-Morales JA, Song CH, Flores LM, Jo EK, Montaño $\mathrm{M}$, et al. A functional promoter polymorphism in monocyte chemoattractant protein-1 is associated with increased susceptibility to pulmonary tuberculosis. J Exp Med. 2005:202(12):1649-58.

28. Centers for Disease Control and Prevention, National Center for Health Statistics. 2000 CDC growth charts: United States. Available from: www.cdc.gov/growthcharts. Accessed on: March 20, 2008.

29. National High Blood Pressure Education Program Working Group on High Blood Pressure in Children and Adolescents. The fourth report on the diagnosis, evaluation, and treatment of high blood pressure in children and adolescents. Pediatrics. 2004;114(2 Suppl):555-76.

30. Matthews DR, Hosker JP, Rudenski AS, Naylor BA, Treacher DF, Turner RC. Homeostasis model assessment: insulin resistance and beta-cell function from fasting plasma glucose and insulin concentrations in man. Diabetologia. 1985;28(7):412-9.

31. Jing Y, Zhu D, BiY, Yang D, HuY, Shen S. Monocyte chemoattractant protein $1-2518 \mathrm{~A} / \mathrm{G}$ polymorphism and susceptibility to type 2 diabetes in a Chinese population. Clin Chim Acta. 2011;412(56):466-9.

32. Price AL, Patterson N, Yu F, Cox DR, Waliszewska A, McDonald GJ, et al. A genomewide admixture map for Latino populations. Am J Hum Genet. 2007;80(6):1024-36.

33. Gonzalez E, Rovin BH, Sen L, Cooke G, Dhanda R, Mummidi S, et al. HIV-1 infection and AIDS dementia are influenced by a mutant MCP-1 allele linked to increased monocyte infiltration of tissues and MCP-1 levels. Proc Natl Acad Sci USA. 2002;99(21):13795-800.

34. Jemaa R, Ben Ali S, Kallel A, Omar S, Feki M, Elasmi M, et al. Association between the -2518G/A polymorphism in the monocyte chemoattractant protein-1 (MCP-1) gene and hypertension in Tunisian patients. Clin Biochem. 2009;42(1-2):34-7.

35. Cai K, Qi D, Hou X, Wang O, Chen J, Deng B, et al. MCP-1 upregulates amylin expression in murine pancreatic $\beta$ cells through ERK/JNK-AP1 and NF-KB related signaling pathways independent of CCR2. PLoS One. 2011;6(5):e19559. 
36. Sell H, Dietze-Schroeder D, Kaiser U, Eckel J. Monocyte chemotactic protein-1 is a potential player in the negative crosstalk between adipose tissue and skeletal muscle. Endocrinology. 2006;147(5):2458-67.
37. Tateya S, Tamori Y, Kawaguchi T, Kanda H, Kasuga M. An increase in the circulating concentration of monocyte chemoattractant protein-1 elicits systemic insulin resistance irrespective of adipose tissue inflammation in mice. Endocrinology. 2010;151(3):971-9. 